Marquette University

e-Publications@Marquette

Biological Sciences Faculty Research and

Publications

Biological Sciences, Department of

$11-1-1996$

A Highly Sensitive Plant Hybrid Protein Assay System Based on the Spm Promoter and TnpA Protein for Detection and Analysis of Transcription Activation Domains

Michael Schläppi

Marquette University, michael.schlappi@marquette.edu

Ramesh Raina

Pennsylvania State University

Nina V. Fedoroff

Pennsylvania State University

Accepted version. Plant Molecular Biology, Vol. 32, No. 4 (November 1996): 717-725. DOI. (C) 1996 Springer. Used with permission.

Michael Schläppi was affiliated with the Carnegie Institution of Washington at the time of publication. 


\title{
A Highly Sensitive Plant Hybrid Protein Assay System Based on the Spm Promoter and TnpA Protein for Detection and Analysis of Transcription Activation Domains
}

\author{
Michael Schläppi \\ Department of Embryology, Carnegie Institution of Washington \\ Baltimore, MD \\ Ramesh Raina \\ Department of Embryology, Carnegie Institution of Washington \\ Baltimore, MD \\ Nina Fedoroff \\ Department of Embryology, Carnegie Institution of Washington \\ Baltimore, MD
}

TnpA is a multifunctional DNA binding protein encoded by the maize Suppressor-mutator (Spm) transposable element. TnpA is required for transposition and is a repressor of the unmethylated Spm promoter. While analyzing protein domains using a yeast GAL4-based hybrid system in transiently transformed tobacco cells, we found that TnpA represses the $>10$ fold transcriptional activation observed when the GAL4 DNA-binding domain is 
NOT THE PUBLISHED VERSION; this is the author's final, peer-reviewed manuscript. The published version may be accessed by following the link in the citation at the bottom of the page.

used alone. By contrast, compared to the backgroundless TnpA DNA-binding domain alone, 33- to 45-fold activation of the Spm promoter was observed when the VP16 activation domain was fused to it. TnpA-binding sites, but no TATA box, were required for transcription activation. Among the TnpA deletion derivatives tested, those retaining the coding sequences for the DNA-binding and protein dimerization domains gave the highest level of transcription activation when fused with the VP16 activation domain. The TnpA gene and TnpA-binding sites in the short Spm promoter therefore provide a novel, highly sensitive single-hybrid system for identifying and studying plant transcription activation domains in plant cells.

\section{Introduction}

The hybrid protein system based on the yeast GAL4 protein and its DNA-binding site is widely used in yeast, mammalian, insect, and plant cells to identify and analyze transcription activation domains [13, 24, $5,12,10,23]$. In this system, a chimeric protein consisting of the GAL4 DNA-binding domain fused to a heterologous transcription activation domain is used to activate transcription from a minimal promoter containing GAL4-binding sites. The assay depends on a transcription factor whose DNA binding and activation functions reside in separate protein domains. The assay is generally performed by cointroducing three plasmids into cells: (1) an 'effector' plasmid carrying a constitutively expressed gene consisting of the GAL4 DNA-binding domain translationally fused to a putative activation domain, (2) a 'reporter' plasmid containing several GAL4-binding sites adjacent to a minimal promoter transcriptionally fused to a reporter gene such as $\beta$ galactosidase, $\beta$-glucuronidase or luciferase (LUC), and (3) an 'internal control' plasmid containing a different, constitutively expressed reporter gene, such as the chloramphenicol acetyl transferase (CAT) gene, to normalize for transformation efficiency. The ratio of reporter gene activity to that of the internal control gene permits quantification of transcriptional activation by the hybrid protein.

The single-hybrid system based on the GAL4 DNA-binding domain has been adapted for analyzing protein activation domains in cultured maize cells $[10,18,11]$. However, the GAL4 DNA-binding domain itself stimulates reporter gene expression in maize cells [10]. While analyzing different TnpA protein domains, we have likewise found that the GAL4 DNA-binding domain has a significant ability to

Plant Molecular Biology, Vol. 32, No. 4 (November 1996): pg. 717-725. DOI. This article is @ Springer and permission has been granted for this version to appear in e-Publications@Marquette. Springer does not grant permission for this article to be further copied/distributed or hosted elsewhere without the express permission from Springer. 
activate transcription in tobacco suspension cells. Thus, the GAL4based assay has a relatively high background in both of these plant cell systems. Here we show as an alternative that the promoter of the maize Suppressor-mutator (Spm) transposable element and the TnpA protein encoded by the transposon can be used to detect transcription activation domains. Unlike the GAL4 DNA-binding domain, neither the complete TnpA protein nor its DNA-binding domain activate transcription. Indeed, TnpA is a transcriptional repressor of its own promoter when analyzed in transiently transformed tobacco cells [2, 20]. However, when a transcription activation domain is translationally fused to the TnpA DNA-binding domain, the fusion protein becomes a strong transcriptional activator. Thus the TnpA DNA-binding domain and the Spm promoter provide the basis of a new, highly sensitive plant-specific system for identifying and analyzing the transcription activation domains of putative transcriptional activators.

\section{Materials and Methods}

\section{Constructs for transient expression assays}

Diagrams of the GAL4-containing effector plasmids and the hybrid GAL4/CaMV promoter LUC reporter plasmid are shown in Fig. $1 \mathrm{~A}$ and Fig. 1B, respectively. GAL4/VP 16 [23] is a derivative of plasmid PPHI 1210 obtained from Pioneer Hi-Bred International, Johnston, Iowa (kindly provided by Ben Bowen and Brad Roth). pPHI1210 has a translational fusion of the yeast GAL4-binding domain (amino acids (a.a.) 1 to 147 [9]) to the strong VP16 activation domain (a.a. 413 to 490, from herpes simplex virus [22]) inserted as a BamHI fragment (in the antisense orientation) in a pUC8-derived dicot expression vector containing an enhanced cauliflower mosaic virus (CaMV) 35S promoter (nucleotides -421 to +2 , repeating-421 to -90 in tandem [7]), and the terminator sequence from the potato proteinase inhibitor II (pinll) gene (nucleotides 2 to 310 [1]). An effector plasmid containing the sense orientation of the GAL4/VP16 fusion was made by insertion of the BamHI fragment from pPHI1210 back into BamHI-cut pPHII 210 to give plasmid pMS231. GAL4/VP16 was made by bluntend self-ligation of pMS231, partially cut, and filled in at the 5' BamHI site flanking the CaMV $35 \mathrm{~S}$ promoter to give plasmid pMS232. The following constructs are all based on pMS232. GAL4 was made by

Plant Molecular Biology, Vol. 32, No. 4 (November 1996): pg. 717-725. DOI. This article is @ Springer and permission has been granted for this version to appear in e-Publications@Marquette. Springer does not grant permission for this article to be further copied/distributed or hosted elsewhere without the express permission from Springer. 
blunt-end self-ligation of pMS232, cut and filled in at the ClaI and NcoI sites to give plasmid pMS236. GAL4/A[3-621] has almost full-length TnpA (a.a. 3 to 621 replacing VP16) translationally fused to the GAL4binding domain inserted as an ECORV-HInclI fragment from pMS335 into pMS232, cut and filled in at the ClaI and BamHI sites to give plasmid pMS336. Plasmid pMS335 was made by site-directed mutagenesis of the tnpA cDNA in pRR466 [20] using oligo-nucleotides 5'-CAGGATGGATATCTCTGGTAGG-3' and 5'CCAACAGGTTGACTTAATATGG-3' to introduce ECORV and HInclI sites at the $5^{\prime}$ and 3 ' end, respectively (mismatch in bold-face type).

GAL4/A[1-120] has the $\mathrm{N}$-terminus of TnpA (a.a. 1 to 120 replacing VP16) inserted as a HInclI-BamHI frag-ment from pMS242 in pMS232 cut with ClaI and BamHI (with filled in ClaI site) to give plasmid pMS243. Plasmid pMS242 was made by inserting an EcoRV-HInclI fragment from pRR483/C1 into the EcoRV site of pBluescript II $\mathrm{KS}(+)$. GAL4/A[422621 ] has the dimerization domain and the C-terminus of TnpA (a.a. 422 to 621 replacing VP16) inserted as a ClaI-BamHI fragment from pMS225 in ClaI-BamHI-cleaved pMS232 to give plasmid pMS238. Plasmid pMS225 was made by blunt-end self-ligation of pMS221, partially cut and filled in at the ClaI site $3^{\prime}$ of tnpA. Plasmid pMS221 contains a filled-in NcoI-SalI fragment of tnpA from pMSI78 [20] inserted in the EcoRV site of pBluescript II KS(+).

GAL4/A[543621 ] has the C-terminus ofTnpA (a.a. 543 to 621 replacing VPI6) inserted as a ClaI-BamHI fragment from pMS226 into pMS232 to give plasmid pMS240. Plasmid pMS226 was made by selfligation of PstI-cut pMS219, containing a filled-in NcoI-SalI tnpA fragment from pMS177 [20] inserted in the ECoRV site of pBluescript II $\mathrm{KS}(+)$. GAL4/A[422-518] has the dimerization domain of TnpA (a.a. 422 to 518, replacing VPI6) inserted as a ClaI-BamHI fragment from pMS265 (made by self-ligation of pMS221 cut with PstI) into pMS232 to give plasmid pMS267. The LUC reporter plasmid pDP1446 (kindly provided by Ben Bowen and Brad Roth [23]) contains five 17-mer binding sites for GAL4 [9], a truncated CaMV 35 S promoter ( -59 to $+2 ;[7])$, the coding region of firefly luciferase (+53 to 1708 [3]), and the pinII terminator. The CAT reference plasmid pDC155 has been described previously [17].

Diagrams of the TnpA-containing effector plasmids and the Spm LUC containing reporter plasmids are shown in Fig. 3A and Fig. 3B,

Plant Molecular Biology, Vol. 32, No. 4 (November 1996): pg. 717-725. DOI. This article is @ Springer and permission has been granted for this version to appear in e-Publications@Marquette. Springer does not grant permission for this article to be further copied/distributed or hosted elsewhere without the express permission from Springer. 
respectively. All effector plasmids are derived from pMS234, made by blunt-end self-ligation of pMS231, partially cut, and filled in at the $3^{\prime}$ BamHI site flanking VP16. A[1-120]/VP16 has the N-terminus of TnpA (a.a. 1 to 120 replacing GAL4) translationally fused to the VP16 activation domain inserted as a BamHI-HInclI frag-ment from pMS185 [20] in pMS234, cut with BamHI and ClaI (with a filled-in ClaI site), to give plasmid pMS245. A[ 1-422]/VP16 has the $\mathrm{N}$-terminus and the DNA-binding domain of TnpA (a.a. 1 to 422 replacing GAL4) inserted as a BamHI-HInclI fragment from pMS186 [20] in pMS234 to give plasmid pMS247. A[1-543]/VP 16 has the N-terminus, the DNAbinding domain, and the dimerization domain of TnpA (a.a. 1 to 543 replacing GAL4), inserted as a BamHI-HIncII fragment from pMS187 [20] in pMS234 to give plasmid pMS249. The UCR-LUC reporter plasmid pDC184 was assembled in pDC107 [17] as follows. The Spm promoter sequence, initially designated the upstream control region or UCR, was inserted as a HindlII-BamHI fragment from pDC121 [17] into HindlII-BamHI-cleaved pDC 107 to give plasmid pDC164, replacing the CaMV 35 S promoter with the UCR. A HindIII-PstI fragment containing the CaMV 35S terminator sequence from pDC176 was inserted upstream of the UCR into HindIII-PstI-cleaved pDC 164 to give plasmid pMS184. The Spm 3'1-LUC reporter plasmid pMS286 was assembled in pMS231 as follows. The Spm 3' end was inserted as an XhoI-AseI fragment (with a filled-in AseI site) from pSpm (Xho) [15] into XhoI-Asp718-cleaved pMS231 (with filled-in Asp718 site) to give pMS274. The CaMV 35S-Ga14 sequence was removed by blunt-end self-ligation of pMS274, cut and filled in at the NotI and XhoI sites, to give plasmid pMS281. Spm 3'-1-1uciferase was made by insertion of a BamHI-Asp718 luciferase fragment (with filled-in Asp718 site) from pDC184 into BgllI-NcoI-cleaved pMS281 (with filled-in NcoI site) to give plasmid pMS286. The Spm 3'-2-LUC reporter plasmid pMS288 was assembled the same way as pMS286, containing an XhoI-Bsu36I fragment from $\mathrm{pSpm}($ Xho $)$ instead.

\section{Transient expression assay}

Plasmids were introduced into tobacco suspension cell cultures using the particle gun (Biolistic PDS1000/He System, BioRad) as previously described $[19,17]$. The suspension cells were collected on

Plant Molecular Biology, Vol. 32, No. 4 (November 1996): pg. 717-725. DOI. This article is @ Springer and permission has been granted for this version to appear in e-Publications@Marquette. Springer does not grant permission for this article to be further copied/distributed or hosted elsewhere without the express permission from Springer. 
filter paper disks (Whatman, No. 1001042) by vacuum filtration, and the filters were placed on medium containing Murashige and Skoog (MS) salts (Gibco), 0.8\% agar (Difco), 3\% sucrose (Sigma), and 0.2 $\mathrm{mg} /$ liter 2,4-dichlorophenoxyacetic acid (2,4-D; Gibco) The SR1 suspension cell culture was established from pith tissue as previously described [20] and subcultured every 7 days in liquid MS medium containing $3 \%$ sucrose and $0.2 \mathrm{mg} / \mathrm{liter} 2,4-\mathrm{D}$. In some experiments, NT1 suspension cell cultures were used [19]. Plasmid DNA was coated onto $1.1 \mu \mathrm{m}$ tungsten particles (M17, BioRad) for bombardment into midlog SR1 tobacco suspension cells (4 days after subculture). 47.5 mg tungsten particles were washed in $100 \%$ ethanol, resuspended in $0.5 \mathrm{ml}$ of $50 \%$ glycerol, and $22 \mu \mathrm{l}$ of the particle suspension was mixed with $22.5 \mu \mathrm{l}$ of a DNA solution containing $1 \mu \mathrm{g}$ each of effector and reporter plasmid and $0.5 \mu \mathrm{g}$ of the CAT reference plasmid (pDC155) in a microcentrifuge tube. With continuous shaking, $37.5 \mu \mathrm{l}$ of $2.5 \mathrm{M}$ $\mathrm{CaCl} 2$ and $15 \mu \mathrm{l}$ of $0.1 \mathrm{M}$ spermidine (free base, Sigma) were added, and the suspension was mixed for $5 \mathrm{~min}$. The tungsten particles were pelleted by brief centrifugation, washed with $70 \%(\mathrm{v} / \mathrm{v})$ ethanol, and resuspended in 25 \# 1 of $100 \%$ ethanol. Aliquots of $6 \mu$ l each were transferred onto microcarriers and air-dried. The tobacco suspension cells were bombarded by these particles under 84.7 to $94.8 \mathrm{kPa}$ vacuum with the particle gun using 7.6 MPa rupture disks. Each sample was bombarded in triplicate and the cells were incubated at room temperature for 16 to $18 \mathrm{~h}$.

\section{Reporter gene assays}

LUC and CAT activities were measured in duplicate as previously described [17]. Extracts were made by grinding the tobacco cells in $0.4 \mathrm{ml}$ of buffer $(0.1 \mathrm{M}$ Tris $\mathrm{pH} 7.8,1 \mathrm{mM}$ dithiothreitol, $0.1 \mathrm{mg} / \mathrm{ml}$ bovine serum albumin (BSA)) for $1 \mathrm{~min}$ and centrifugation at 12000 rpm for 3 rain. No more than 4 extracts were prepared at one time, kept on ice, and processed immediately. LUC activity was determined

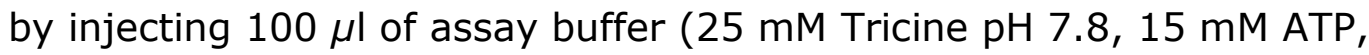
$0.5 \mathrm{mg} / \mathrm{ml} \mathrm{BSA}$ ) into $50 \mu \mathrm{l}$ of supernatant and initiating the reaction by immediately injecting $100 \mu$ of $0.5 \mathrm{mM}$ luciferin (Sigma) into the mixture. Peak light intensity was measured in a Monolight 1500 (Analytical Luminescence Laboratory, San Diego). The remaining extract was incubated at $60^{\circ} \mathrm{C}$ for 10 rain and centrifuged at 12000 rpm for $3 \mathrm{~min}$, then frozen at $-70^{\circ} \mathrm{C}$. For each CAT assay, 20 \# 1 of

Plant Molecular Biology, Vol. 32, No. 4 (November 1996): pg. 717-725. DOI. This article is (c) Springer and permission has been granted for this version to appear in e-Publications@Marquette. Springer does not grant permission for this article to be further copied/distributed or hosted elsewhere without the express permission from Springer. 
the supernatant was transferred to a fresh tube containing $100 \mu \mathrm{l}$ of CAT assay buffer $(0.1 \mathrm{M}$ Tris $\mathrm{pH} 7.8,5 \mu \mathrm{l}$ of $5 \mathrm{mg} / \mathrm{ml} 1$-butyryl CoA (Sigma), $1.75 \mu \mathrm{l}$ of $50 \mu \mathrm{Ci} / \mathrm{ml}\left[{ }^{14} \mathrm{C}\right]$ chloramphenicol (NEN; $1 \mu \mathrm{Ci}=37$ $\mathrm{GBq})$ ). Samples were incubated at $37^{\circ} \mathrm{C}$ for 1 hour, extracted with $300 \mu$ of mixed xylene (Baxter), and centrifuged for 5 min at 12000 rpm. The organic phase was transferred to a fresh tube, back extracted twice with $200 \mu$ of $0.1 \mathrm{~m}$ Tris, $\mathrm{pH} 7.8$, and the radioactivity in $50 \mu$ of the organic phase was counted in a liquid scintillation counter using $5 \mathrm{ml}$ of scintillation fluid.

LUC-to-CAT ratios of the three replicates were calculated for each sample and the mean value and standard deviation determined.

\section{Results}

\section{TnpA represses transcriptional activation by the GAL4 DNA-binding domain in plant cells}

The full-length TnpA coding sequence and 5'- and 3 '- terminal deletion derivatives of TnpA were fused to the yeast GAL4 DNA-binding domain and tested for their ability to affect transcription of a LUC reporter gene expressed from a minimal plant promoter containing GAL4 binding sites (Fig. 1; [9, 21, 20]). The Herpes Simplex VP16 activation domain fused to the GAL4 DNA-binding domain served as a positive control [22]. The effect of the fusion genes was compared with the baseline transcriptional activation observed with the GAL4binding domain in plant cells. Effector plasmid DNAs carrying the various translational fusions were coated onto tungsten particles together with a GAL4-binding site-containing LUC reporter plasmid (Fig. 1B) and introduced into tobacco suspension cells by microprojectile bombardment $[19,17]$. A plasmid containing a bacterial CAT gene expressed from the CaMV 35S promoter was used to normalize for transformation efficiency. LUC and CAT activities were assayed $18 \mathrm{~h}$ after introduction of the DNA and the ratio of LUC to CAT activity was calculated to correct for between-experiment variation. The LUC/CAT ratios obtained with different constructs were then compared with the relevant control by calculating the ratio of the LUC/CAT value obtained with an experimental construct to that obtained with the relevant control construct and expressing the ratio

Plant Molecular Biology, Vol. 32, No. 4 (November 1996): pg. 717-725. DOI. This article is @ Springer and permission has been granted for this version to appear in e-Publications@Marquette. Springer does not grant permission for this article to be further copied/distributed or hosted elsewhere without the express permission from Springer. 
as 'relative activation'. Thus, for example, in Fig. $2 \mathrm{~A}$, the reference control value is the LUC/CAT ratio obtained with an antisense effector plasmid, while in Fig. 2B, it is the LUC/CAT value obtained with an effector plasmid expressing the GAL4 DNA-binding domain.

A plasmid containing the coding sequence for the GAL4 DNAbinding domain alone activates the LUC reporter gene more than 10fold in tobacco cells (Fig. 2A; relative activation: $14.3 \pm 4.4$ (LUC/CAT value of GAL4:17.3 \pm 5.45 ; LUC/CAT value of control: $1.27 \pm 0.15)$ ). All of the chimeric genes containing TnpA-coding sequences fused to a sequence encoding the GAL4 DNA-binding domain showed lower levels of LUC expression than that detected with the GAL4 DNA-binding domain sequence alone (Fig. 2A). While these observations are consistent with our previous report that TnpA represses its own promoter [20], the fact that even small segments of the coding sequence are inhibitory suggests that their addition to the GAL4binding domain may serve to interfere with its ability to interact with other proteins, or that the fusion protein becomes unstable. When the strong VPI6 activation domain is fused to the GAL4 DNA-binding domain, expression of the reporter gene is stimulated only an additional 10-fold over the back-ground value observed with the GAL4 DNA-binding domain alone (Fig. 2B; relative activation: $10.9 \pm 0.9$ (LUC/CAT value of GAL4/VP16: $188 \pm 15$; LUC/CAT value of GAL4: $17.3 \pm 5.45)$ ). Thus the GAL4-based system is relatively insensitive for studying weak activation domains in plant cells because of the high basal activation observed with the GAL4 DNA-binding domain alone.

\section{TnpA/VP16 fusions activate transcription from the Spm promoter and from DNA motifs containing TnpA-binding sites}

As previously reported, TnpA represses its own pro-moter [2, 20]. The Spm promoter is short $(0.2 \mathrm{~kb})$ and contains nine $12 \mathrm{bp}$ TnpA-binding sites $[8,17]$. To determine whether TnpA can be converted from a repressor into an activator by addition of a strong activation domain, the coding sequence of the VP16 activation domain was fused to different deletion derivatives of the TnpA coding sequence (Fig. 3A). TnpA and TnpA/VP16 fusion gene plasmids were

Plant Molecular Biology, Vol. 32, No. 4 (November 1996): pg. 717-725. DOI. This article is @ Springer and permission has been granted for this version to appear in e-Publications@Marquette. Springer does not grant permission for this article to be further copied/distributed or hosted elsewhere without the express permission from Springer. 
co-bombarded into tobacco suspension cells with reporter plasmids in which the LUC gene was expressed from the Spm promoter (Fig. 3B). In contrast to the GAL4 DNA binding domain, which itself stimulates LUC expression substantially (Fig. 2), TnpA constructs lacking VP16 do not activate the weak Spm promoter (Table 1, data for A[1-543]). Instead, expression of TnpA constructs containing the DNA-binding and dimerization domains repress the Spm promoter, as previously reported (Fig. 4a, insert; LUC/CAT of vector control: $3.1 \pm 0.69 ;$ [20]).

Expression of plasmids carrying certain TnpA-VP16 fusions activate transcription of the LUC gene from the Spm promoter (Figs. 3 and 4 ). A fusion of the VP16 activation domain to the first 120 amino acids of TnpA does not activate expression of the LUC gene (Fig. 4A), while VP16 fusions containing the TnpA DNA-binding domain do. A VP16-TnpA fusion protein which contains the TnpA-binding domain, but lacks the protein dimerization domain stimulates promoter activity 21-fold over that observed with $A[1-422]$ alone (Fig. 4A, $A[1-$ 422]/VP16). The VP16 fusion gene containing both the DNA-binding and the protein dimerization domains of TnpA is the strongest activator (Fig. 4A, A[1-543]/VP16). Relative to $A[1-543]$ alone, the A[1-543]/VP16 fusion activates the Spm promoter more than 30-fold (relative activation: $34.0 \pm 1.79$; LUC/CAT value of $\mathrm{A}[1543] / V P 16: 62.21 \pm 3.27 ;$ LUC/CAT value of $\mathrm{A}[1543]: 1.83 \pm$ $0.56)$. The range of promoter activation varied between 33 and 45 -fold in four independent experiments conducted on different days and with different tobacco suspension cell lines. Thus the addition of an activation domain to TnpA converts it to a strong activator of the Spm promoter. To demonstrate the reliability of the VP16/TnpA/Spm promoter hybrid system, LUC and CAT values of three replicates from three independent experiments are shown in Table 1.

Two observations suggest that the TnpA-binding sites are the most important determinant of the Spm promoter's response to the VP16-TnpA fusions. First, the element's 3'-end, whose sequence organization resembles that of the 5 ' end and contains 15 TnpAbinding sites (Fig. 3B $[14,8]$ ) can substitute for the Spm promoter in the present assay. As shown in Fig. 4B, the A[1-543]/VP 16 fusion activates expression of the LUC gene from two different Spm 3' end fragments by 20 -to 40 -fold. Second, the Spm promoter is a TATA-less

Plant Molecular Biology, Vol. 32, No. 4 (November 1996): pg. 717-725. DOI. This article is @ Springer and permission has been granted for this version to appear in e-Publications@Marquette. Springer does not grant permission for this article to be further copied/distributed or hosted elsewhere without the express permission from Springer. 
promoter [17] and addition of a TATA box at -30 from the transcription start site does not further enhance the ability of a VP16-TnpA fusion protein to activate the LUC gene from the Spm promoter (data not shown). This may be because -30 partially overlaps with the last TnpA binding site in the Spm promoter. Because TnpA is normally a repressor of its own promoter in transient assays, compared to GAL4 the DNA-binding domain of TnpA does not further enhance the baseline or background activity of the Spm promoter, providing a highly sensitive plant-specific system for detecting and analyzing transcription activation domains of proteins.

\section{Discussion}

Although the yeast hybrid fusion protein system for analyzing protein activation domains based on the GAL4 DNA binding domain has been adapted for use in cultured plant cells, it has proved to have significant background activity in both maize and tobacco cells [10, this study]. The GALA DNA-binding domain itself stimulates reporter gene expression in both types of cells. In the present experiments, plasmids carrying the coding sequence for the GAL4 DNA-binding domain stimulated transcription of a LUC reporter gene in tobacco cells by more than an order of magnitude. Addition of a strong activation domain, that of the herpes simplex VP16 protein, to the GAL4 DNAbinding domain stimulates reporter gene expression by only another order of magnitude over that observed with the GAL4 DNA-binding domain alone, making the assay relatively insensitive for detecting and analyzing plant transcription activation domains significantly weaker than that of the VP16 protein.

The Spin promoter is 50 - to 100 -fold weaker than the complete, enhancer-containing cauliflower mosaic virus (CaMV) 35 S promoter, and its activity is comparable to that of the minimal CaMV $35 \mathrm{~S}$ promoter lacking enhancer sequences, having 5- to 10-fold higher LUC values than the Monolight 1500 machine background (data not shown; [17]). The Spm promoter sequence is co-extensive with the sequence at the $5 \mathrm{t}$ end of the element containing multiple binding sites for the element-encoded TnpA protein, which functions in transposition and is both a positive and negative regulator in vivo $[6,16,2,20$, for review 4]. TnpA has been subdivided experimentally into four different

Plant Molecular Biology, Vol. 32, No. 4 (November 1996): pg. 717-725. DOI. This article is (c) Springer and permission has been granted for this version to appear in e-Publications@Marquette. Springer does not grant permission for this article to be further copied/distributed or hosted elsewhere without the express permission from Springer. 
domains: an N-terminal sequence required for transposition (a.a 1 to 120), a DNA-binding domain (a.a. 120 to 422), a protein dimerization domain (a.a. 422 to 543), and a C-terminal sequence (a.a. 543 to 621 ) required for transposition and activation of the methylated Spm promoter $[21 ; 20]$.

In a yeast GALA-based hybrid protein expression system adapted for use in plant cells, both intact TnpA and deletion derivatives of it interfere with the ability of the GAL4 DNA-binding domain to activate transcription of a LUC reporter gene. Expression of the GAL4-binding domain coding sequence consistently stimulates LUC reporter gene expression more than 10 -fold in tobacco cells relative to the expression level observed in its absence from a minimal 35S promoter with adjacent GAL4-binding sites. Plasmids expressing translational fusions of the GAL4 DNA-binding domain with either the complete or a deleted TnpA-coding sequence stimulate LUC reporter gene expression by only 2 - to 5 -fold relative to expression from the hybrid promoter alone. Thus, the addition of TnpA-coding sequences depresses the ability of the GAL4 DNA binding domain to activate the minimal 35S promoter. While this is consistent with TnpA's known repressor activity, it seems unlikely that it is a reflection of it. This is because all tested TnpA fragments have the same effect as fusion proteins, while the protein's DNA-binding and protein dimerization domains are required for repression of the Spm promoter [20]. Fusion of TnpA protein fragments to the GAL4 DNAbinding domain may interfere with transcription by preventing other proteins from interacting with the GAL4 protein or by steric hindrance of protein-DNA interactions. It is likewise possible that addition of protein domains lacking transcriptional activity simply destabilizes the GAL4 fusion protein, since 3-to 4-fold repression of GAL4 background activity is also observed with fusions to the C-terminus of TnpD, the other Spmspecific protein (data not shown).

When a VP16 transcription activation domain is translationally fused with either the complete TnpA protein or a deletion derivative retaining the DNA binding and protein-dimerization domains, TnpA is converted from a repressor of its own promoter to a strong activator. Not surprisingly, the VP16-TnpA construct including the protein dimerization domain is a stronger activator than a similar construct

Plant Molecular Biology, Vol. 32, No. 4 (November 1996): pg. 717-725. DOI. This article is @ Springer and permission has been granted for this version to appear in e-Publications@Marquette. Springer does not grant permission for this article to be further copied/distributed or hosted elsewhere without the express permission from Springer. 
lacking the dimerization domain. This may be a simple con-sequence of the ability of the protein dimer to bringing more VPI6 protein to the promoter. Because TnpA alone represses the Spm promoter, the ability of an activation domain to convert it to a strong activator provides the basis of a novel, sensitive, plant fusion protein system for detecting and analyzing transcription activation domains. In the present experiments, LUC activity was 3345 times the background value using the VP16/TnpA/Spm promoter hybrid system, as compared with only about 10-fold over background with the VPI 6/GAL4 system in plant cells. Even when VPI6 was fused to GAL4FFnpD, which has 3-to 4-fold less background activity than GAL4, the relative activation of GAL4/TnpD/VPI6 again was only 10-fold compared to GAL4FFnpD alone (data not shown). Thus, while the absolute LUC/CAT values of the activation were about 3-fold lower for the Spm promoter-based hybrid protein system, the higher sensitivity of the system permits detection and analysis of much weaker activation domains than the GAL4-based sys-tem. Moreover, this plant-based hybrid system may permit detection of transcription activation domains that require plantspecific co-factors.

\section{Acknowledgments}

We would like to thank Mary Strem and Adam Elhofy for technical assistance and Ben Bowen and Brad Roth (Pioneer Hi-Bred International, Johnston, IO) for plasmids pPHI1210 and pDP1446. We thank Ben Bowen, Vicki Chandler, Brad Roth and David Smith for critical discussions. This research was supported by National Institute of Health Grant GM34296. M.S. was supported by advanced researcher grant 84FI-037132 of the Swiss National Science Foundation and by the Camegie Institution of Washington.

Plant Molecular Biology, Vol. 32, No. 4 (November 1996): pg. 717-725. DOI. This article is @ Springer and permission has been granted for this version to appear in e-Publications@Marquette. Springer does not grant permission for this article to be further copied/distributed or hosted elsewhere without the express permission from Springer. 
NOT THE PUBLISHED VERSION; this is the author's final, peer-reviewed manuscript. The published version may be accessed by following the link in the citation at the bottom of the page.

\section{References}

1. An G, Mitra A, Choi HK, Costa MA, An K, Thornburg RW, Ryan CA: Functional analysis of the $3^{\prime}$ control region of the potato woundinducible proteinase II gene. Plant Cell 1:115122 (1989).

2. Cook D, Fedoroff N: Regulation of Spm promoter activity by Spmencoded tnpA gene product and DNA methylation. Maize Genet Coop Newsl 66:11-12 (1992).

3. deWet JR, Wood KV, DeLuca M, Helinski DR, Subramani S: Firefly luciferase gene: structure and expression in mammalian cells. Mol Cell Biol 7:25-37 (1987).

4. Fedoroff N, Schläppi M, Raina R: Epigenetic regulation of the maize Spin transposon. BioEssays 17:291-297 (1995).

5. Fisher JA, Giniger E, Maniatis T, Ptashne M: GAL4 activates transcription in DrosopHI/a. Nature 332:853-856 (1988).

6. Frey M, Reinecke J, Grant S, Saedler H, Gierl A: Excision of the $\mathrm{En} / \mathrm{Spm}$ transposable element of Zea mays requires two element-encoded proteins. EMBO J 9:4037-4044 (1990).

7. Gardner RC, Howarth AJ, Hahn P, Brow-Luedi M, Wilson TMA: The complete nucleotide sequence of an infectious clone of cauliflower mosaic virus by $\mathrm{M} 13 \mathrm{mp} 7$ shot-gun sequencing. Nucl Acids Res 15:3257-3273 (1981).

8. Gierl A, Lütticke S, Saedler H: TnpA product encoded by the transposable element En-1 of Zea mays is a DNA binding protein. EMBO J 7:4045-4053 (1988).

9. Giniger E, Varnum SM, Ptashne M: Specific DNA binding of Gal4, a positive regulatory protein of yeast. Cell 40:767-774 (1985).

10. Goff SA, Cone KC, Fromm ME: Identification of functional domains in the maize transcriptional activator $\mathrm{C} \mathrm{I}$ : comparison of wildtype and dominant inhibitor proteins. Genes Devel 5: 298-309 (1991).

11. Goff SA, Cone KC, Chandler VL: Functional analysis of the transcriptional activator encoded by the maize $B$ gene: evidence

Plant Molecular Biology, Vol. 32, No. 4 (November 1996): pg. 717-725. DOI. This article is @ Springer and permission has been granted for this version to appear in e-Publications@Marquette. Springer does not grant permission for this article to be further copied/distributed or hosted elsewhere without the express permission from Springer. 
NOT THE PUBLISHED VERSION; this is the author's final, peer-reviewed manuscript. The published version may be accessed by following the link in the citation at the bottom of the page.

for a direct functional interaction between two classes of regulatory proteins. Genes Devel 6:864--875 (1992).

12. Ma J, Przibilla E, Hu J, Bogorad L, Ptashne M: Yeast activators stimulate plant gene expression. Nature 334:631-633 (1988).

13. Ma J, Ptashne M: A new class of yeast transcriptional activators. Cell 51:113-119 (1987).

14. Masson P, Surosky R, Kingsbury J, Fedoroff NV: Genetic and molecular analysis of the Spm-dependent $a-m 2$ alleles of the maize a locus. Genetics 177:117-137 (1987).

15. Masson P, Fedoroff NV: Mobility of the maize Suppressor-mutator element in transgenic tobacco cells. Proc Natl Acad Sci USA 86:2219-2223 (1989).

16. Masson $\mathrm{P}$, Strem $\mathrm{M}$, Fedoroff $\mathrm{N}$ : The tnpA and tnpD gene products of the Spm element are required for transposition in tobacco. Plant Cell 3:73-85 (1991).

17. Raina R, Cook D, Fedoroff N: Maize Spm transposable element has an enhancer-insensitive promoter. Proc Natl Acad Sci USA 90:6355-6359 (1993).

18. Roth BA, Goff SA, Klein TM, Fromm ME: $C l$ - and $R$-dependent expression of the maize $B z 1$ gene requires sequences with homology to mammalian myb and $m y c$ binding sites. Plant Cell 3:317-325 (1991).

19. Russell JA, Roy MK, Sandford JC: Major improvements in biolistic transformation of suspension-cultured tobacco cells. In Vitro Cell Devel Biol 28:97-105 (1992).

20. Schläppi M, Raina R, Fedoroff N: Epigenetic regulation of the maize Spm transposable element: novel activation of a methylated promoter by TnpA. Cell 77:427-437 (1994).

21. Trentmann SM, Saedler $H$, Gierl A: The transposable element En/Spm-encoded TNPA protein contains a DNA binding and a dimerization domain. Mol Gen Genet 238:201-208 (1993).

Plant Molecular Biology, Vol. 32, No. 4 (November 1996): pg. 717-725. DOI. This article is (c) Springer and permission has been granted for this version to appear in e-Publications@Marquette. Springer does not grant permission for this article to be further copied/distributed or hosted elsewhere without the express permission from Springer. 
NOT THE PUBLISHED VERSION; this is the author's final, peer-reviewed manuscript. The published version may be accessed by following the link in the citation at the bottom of the page.

22. Triezenberg SJ, Kingsbury RC, McKnight SL: Functional dissection of VP16, the transactivator of herpes simplex virus intermediate early gene expression. Genes Devel 2:718-729 (1988).

23. Unger E, Pearson RL, Schmidt RJ, Bowen B, Roth BA: Dominant negative mutants of opaque2 suppress transactivation of a 22$\mathrm{kD}$ zein promoter by opaque 2 in maize endosperm cells. Plant Cell 5:831-841 (1993).

24. Webster N, Jin JR, Gree S, Hollis M, Chambon P: The yeast UASG is a transcriptional enhancer in human HeLa cells in the presence of the GAL4 trans-activator. Cell 52:169-178 (1988). 


\section{Appendix}

Figure 1: Schematic representation of the GAL4 fusion genes and the luciferase reporter gene.

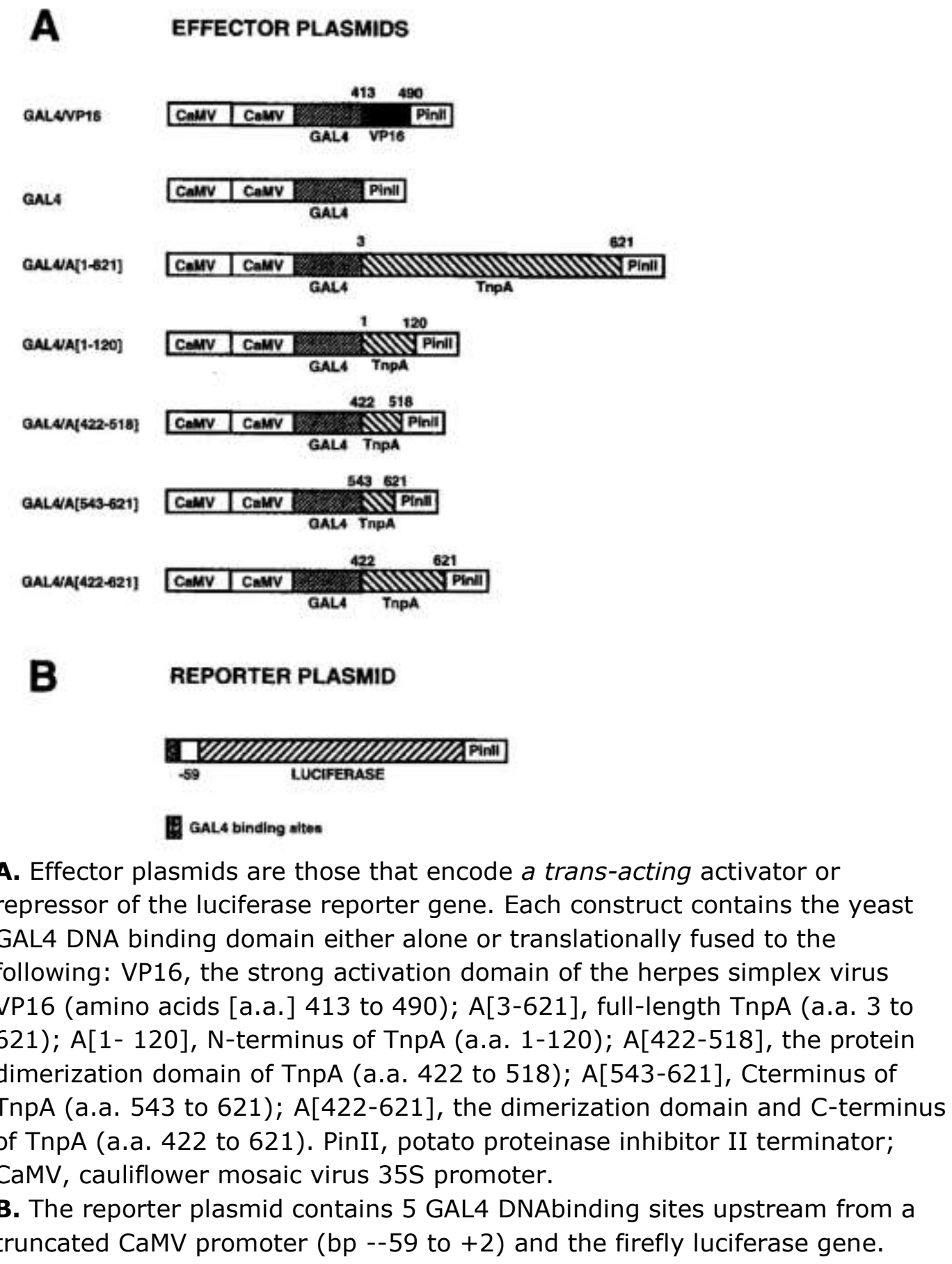

Plant Molecular Biology, Vol. 32, No. 4 (November 1996): pg. 717-725. DOI. This article is (c) Springer and permission has been granted for this version to appear in e-Publications@Marquette. Springer does not grant permission for this article to be further copied/distributed or hosted elsewhere without the express permission from Springer. 
NOT THE PUBLISHED VERSION; this is the author's final, peer-reviewed manuscript. The published version may be accessed by following the link in the citation at the bottom of the page.

Figure 2: Expression of a GAL4-LUC reporter gene in the presence of GAL4-TnpA and GAL4-VP16 effector plasmids.

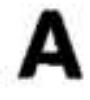

\section{Relative Activation}

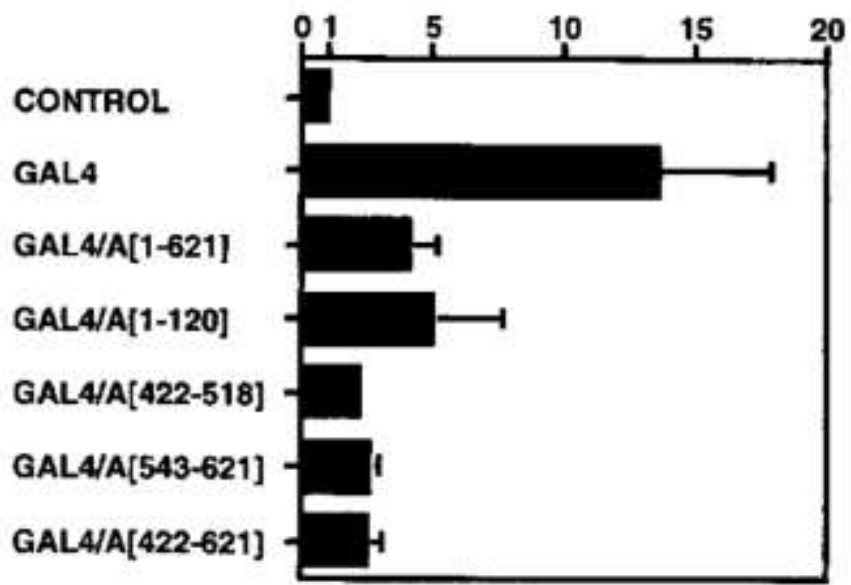

Relative Activation

GAL4

GAL4/NP16

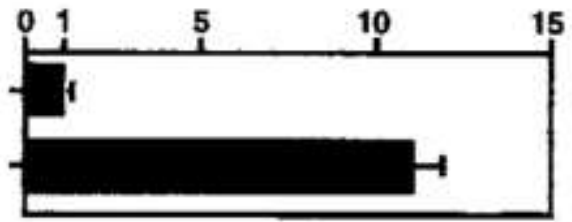

A. Relative activation of the LUC reporter gene in tobacco suspension cells by expression of the chimeric GAL4/TnpA genes shown in Fig. 1. The activity of the test plasmid was measured and normalized to an internal CAT control as described in Materials and methods. Relative activation represents the ratio of normalized LUC activity obtained in the presence of a GAL4- or a GAL4/TnpA effector plasmid to that observed with an effector plasmid carrying an antisense GAL4/VP 16 construct. The LUC reporter plasmid contains GAL4 DNA binding sites and a minimal CaMV $35 \mathrm{~S}$ promoter (Fig. 1B).

B. Activation of the LUC reporter gene by the chimeric GAL4/VP16 construct shown in Fig. I. Relative activation is the ratio of normalized LUC activity observed in the presence of the GAL4/VP16 fusion to that observed with GAL4-binding domain alone.

Plant Molecular Biology, Vol. 32, No. 4 (November 1996): pg. 717-725. DOI. This article is @ Springer and permission has been granted for this version to appear in e-Publications@Marquette. Springer does not grant permission for this article to be further copied/distributed or hosted elsewhere without the express permission from Springer. 
NOT THE PUBLISHED VERSION; this is the author's final, peer-reviewed manuscript. The published version may be accessed by following the link in the citation at the bottom of the page.

Figure 3: Schematic representation of chimeric TnpA-VP16 and Spm promoter-Iuciferase reporter genes.

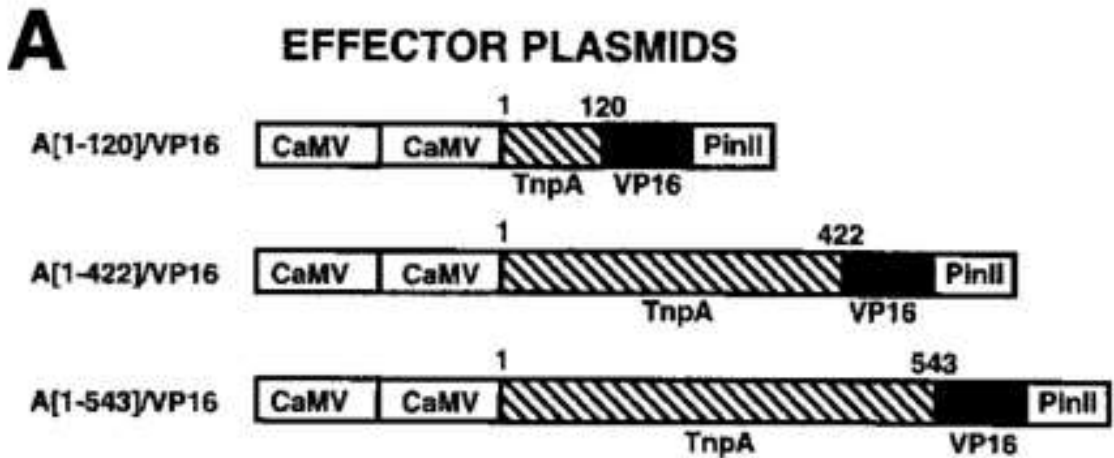

B

REPORTER PLASMIDS

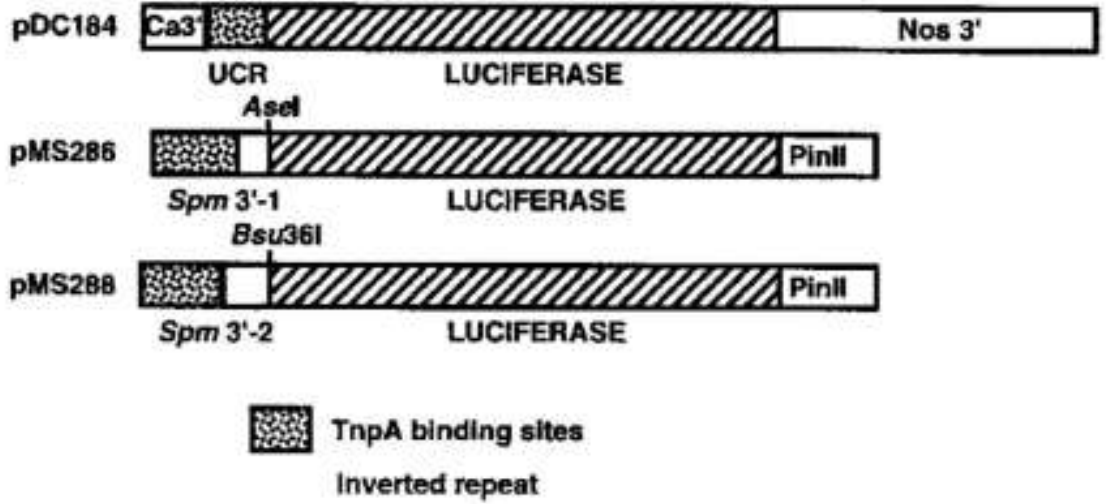

A. Effector plasmids contain translational fusions of the following TnpA domains to the herpes simplex VPI6 activation domain (a.a. 413 to 490): $A[1-120], \mathrm{N}$-terminus of TnpA (a.a. 1 to 120$) ; A[1-422], \mathrm{N}$-terminus and DNA-binding domain of TnpA (a.a. 1 to 422); A[I-543], Nterminus, DNAbinding and protein dimerization domains of TnpA (a.a. I to 543). PinII, potato proteinase inhibitor II terminator; CaMV, cauliflower mosaic virus $35 \mathrm{~S}$ promoter.

B. The firefly LUC gene in the reporter plasmids is expressed from either the UCR promoter sequence of the Spm element, which contains 9 TnpA-binding sites, [ 17], or 1 of 2 different fragments of the Spm $3^{\prime}$-end in the antisense orientation, each containing 15 TnpA binding sites [14; 8]. Nos 3', nopaline synthase terminator. Ca3', CaMV 35S terminator; PinII, potato proteinase inhibitor II terminator.

Plant Molecular Biology, Vol. 32, No. 4 (November 1996): pg. 717-725. DOI. This article is @ Springer and permission has been granted for this version to appear in e-Publications@Marquette. Springer does not grant permission for this article to be further copied/distributed or hosted elsewhere without the express permission from Springer. 
NOT THE PUBLISHED VERSION; this is the author's final, peer-reviewed manuscript. The published version may be accessed by following the link in the citation at the bottom of the page.

Figure 4: Activation of the Spm promoter by TnpA/VP16 fusion proteins in tobacco cells.

A

Relative Activation

UCR + A[1-120]

UCR + AC1-1201VP16

UCR + A[1-422]

UCR + A[1-422]VP16

UCR + A[1-543]

UCR + A[1-543yVP16

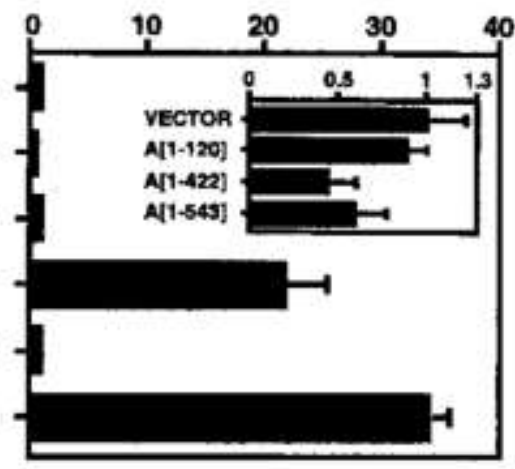

B

Spm 3'-2 + A[1-543]

Spm 3'-2 + A[1-543yNP16

Spm 3'-1 + A[1-543]

Spm 3'-1 + A[1-543]VP16

Relative Activation

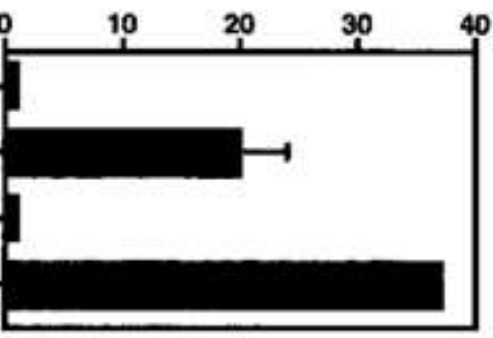

A. Relative activation of UCR-LUC reporter gene expression (Fig. 3B) by the chimeric TnpA/VP16 fusion proteins shown in Fig. 3A. Controls were plasmids carrying the corresponding TnpA gene or gene fragments lacking the VP16 activation domain. LUC activity was measured and normalized as described in Materials and methods. Relative activation is the ratio of normalized LUC activity observed in the presence of the effector plasmid expressing the TnpA/VP16 to that observed with an effector plasmid expressing only the corresponding TnpA gene or gene fragment. The insert shows the corresponding relative activation values for the TnpA gene fragments relative to the bluescript $\mathrm{pKS}(+)$ vector control.

B. Relative activation of two different Spm 3'-LUC reporter gene expressions (Fig. 3B) by chimeric TnpA[1-543]/VP16. The Spm 3' end contains 15 TnpAbinding sites.

Plant Molecular Biology, Vol. 32, No. 4 (November 1996): pg. 717-725. DOI. This article is @ Springer and permission has been granted for this version to appear in e-Publications@Marquette. Springer does not grant permission for this article to be further copied/distributed or hosted elsewhere without the express permission from Springer. 
NOT THE PUBLISHED VERSION; this is the author's final, peer-reviewed manuscript. The published version may be accessed by following the link in the citation at the bottom of the page.

Table 1: Activation of Spm promoter-LUC reporter gene expression by TnpA/VP16.

\begin{tabular}{|c|c|c|c|c|c|c|c|}
\hline & \multicolumn{6}{|c|}{ Effector plasmids and replicates } & \multirow{3}{*}{$\begin{array}{l}\text { Relative } \\
\text { activation }\end{array}$} \\
\hline & \multicolumn{3}{|c|}{$\mathrm{A}[1-543]$} & \multicolumn{3}{|c|}{$\mathrm{A}[1-543] / \mathrm{VP} 16$} & \\
\hline & 1 & 2 & 3 & 1 & 2 & 3 & \\
\hline \multicolumn{8}{|c|}{ Experiment 1} \\
\hline LUC & 3,028 & 2,081 & 1,470 & 143,520 & 40,685 & 71,288 & \\
\hline CAT & 1,071 & 1,220 & 1,240 & 1,195 & 1,017 & 1,345 & \\
\hline LUC/CAT & 2.83 & 1.17 & 1.19 & 97.3 & 40 & 53 & \\
\hline Mean & & $1.19 \pm 0.68$ & & & $63.4 \pm 24.5$ & & $33 \pm 12.9$ \\
\hline \multicolumn{8}{|c|}{ Experiment 2} \\
\hline LUC & 1,411 & 2,788 & 1,263 & 40,341 & 23,273 & 26,258 & \\
\hline CAT & 1,140 & 1,075 & 762 & 641 & 402 & 399 & \\
\hline LUC/CAT & 1.24 & 2.59 & 1.66 & 62.93 & 56.89 & 65.80 & \\
\hline Mean & & $1.83 \pm 0.56$ & & & $62.2 \pm 3.3$ & & $34 \pm 1.79$ \\
\hline \multicolumn{8}{|c|}{ Experiment 3} \\
\hline LUC & 2,129 & 2,063 & 1,430 & 57,318 & 46,029 & 59,228 & \\
\hline CAT & 1,672 & 3,203 & 2,702 & 1,800 & N.D. & 1,410 & \\
\hline LUC/CAT & 1.27 & 0.64 & 0.53 & 31.84 & & 42.01 & \\
\hline Mean & & $0.82 \pm 0.33$ & & & $36.7 \pm 5.0$ & & $45 \pm 6.1$ \\
\hline
\end{tabular}

Plasmid constructs are described in Fig. $3 \mathrm{~A}$ and were delivered to tobacco suspension cells by microprojectiles. LUC and CAT activities were measured as described in Materials and methods. Plasmid A[1-543] lacks the VP16 activation domain. Data from three replicates of three individual experiments are presented. Relative activation values are determined as the ratio of LUC to CAT activities of the plasmids containing VP16 to activities observed with control plasmids containing the TnpA domain alone. N.D., not determined.

Plant Molecular Biology, Vol. 32, No. 4 (November 1996): pg. 717-725. DOI. This article is (C) Springer and permission has been granted for this version to appear in e-Publications@Marquette. Springer does not grant permission for this article to be further copied/distributed or hosted elsewhere without the express permission from Springer. 